\section{Harish-Chandra Research Institute}

Chhatnag Road, Jhusi, Allahabad, Uttar Pradesh 211019, India

Tel: $\quad$ (91) 5322569509

Contact: The Harish-Chandra Research Institute

\section{Postdoctoral Fellowships in Physics at Harish-Chandra Research Institute}

Subjects: Fellowships are awarded in the field of Physics Purpose: The aim of the fellowships is to support Indian students and provide opportunities to researchers working in Astrophysics, Condensed Matter Physics, High Energy Phenomenology, Quantum Information \& Computing, and String Theory

Eligibility: Applicants from India are eligible to apply for the fellowship. Applicants must be researchers

Type: Postdoctoral fellowship

Value: HRI offers opportunities to researchers working in Astrophysics, Condensed matter physics, High energy phenomenology, Quantum information \& computing, and, String theory

Study Establishment: Fellowships are awarded in the field of Physics

Country of Study: India

Application Procedure: See the website

Closing Date: Applications for the fellowships will be considered twice every year, with deadlines on the 15 August and on the 31 December

Additional Information: For more details please visit the website at scholarship-positions.com/postdoctoral-fellowshipsphysics-harish-chandra-research-institute-india/2017/12/26/

\section{For further information contact:}

Email: physvisit@hri.res.in

\section{Harpo Foundation}

\author{
Tel: $\quad$ (1) 7577354269 \\ Website: http://www.harpofoundation.org/
}

The Harpo Foundation was established in 2006 to support emerging visual artists. The foundation seeks to stimulate creative inquiry and to encourage new modes of thinking about art. We view the definitions of art and artist to be open-ended and expansive. The Foundation's grant program awards 7-10 grants annually. Grants are made directly to artists to support their development and to non-profit organizations in support of new work by artists. The Foundation also supports two residency fellowship programs. The Native American Residency Fellowship program provides residency opportunities at the Vermont Studio Center to support the development of artists and the potential for inter-cultural dialog. The Emerging Artist Residency Fellowship program supports residency opportunities at the Santa Fe Art Institute for visual artists 25 years and older who need time and space to explore ideas and start new projects.

\section{Harpo Foundation Grants for Visual Artists}

Subjects: All subjects

Purpose: The Harpo Foundation seeks to stimulate creative inquiry and to encourage new modes of thinking about art. Applications are evaluated on the basis of the quality of the artist's work, the potential to expand aesthetic inquiry, and its relationship to the foundation's priority to provide support to visual artists who are under-recognized by the field

Level of Study: Professional development

Type: Grant

Value: up to $\mathrm{A} \$ 10,000$

Frequency: Varies

Country of Study: Any country 
Application Procedure: Apply online

Closing Date: April

Funding: Foundation

\section{Harry S Truman Library Institute}

500 West United States Highway 24, Independence, MO 64050, United States of America
Tel: $\quad$ (1) 8162688200
Fax: $\quad$ (1) 8162688295
Email: lisa.sullivan@nara.gov
Website: www.trumanlibrary.org
Contact: Lisa Sullivan, Grants Administrator

The Harry S Truman Library Institute is a non-profit partner of the Harry S Truman Library. The institute's purpose is to foster the Truman Library as a centre for research and as a provider of educational and public programmes.

\section{Harry S Truman Library Institute Dissertation Year Fellowships}

Subjects: The public career of Harry S Truman and the history of the Truman administration

Purpose: To encourage historical scholarship in the Truman era Eligibility: Open to graduates who have completed their dissertation research and are ready to begin writing. Dissertations must be on some aspect of the life and career of Harry $\mathrm{S}$ Truman or of the public and policy issues that were prominent during the Truman years

Level of Study: Graduate, Postgraduate

Type: Fellowship

Value: US\$16,000, payable in two instalments

Length of Study: 1 year

Frequency: Annual

Country of Study: United States of America

Application Procedure: Application forms are available from the website

Closing Date: 1 February

Funding: Private

Additional Information: Recipients will not be required to come to the Truman Library but will be expected to furnish the Library with a copy of their dissertation

\section{For further information contact:}

Tel: $\quad$ (1) 8162688248

Fax: (1) 8162688299

Email: sullivan.hstli@gmail.com

\section{Harry S Truman Library Institute Scholar's Award}

Eligibility: An applicant's work should be based in part on extensive research at the Truman Library and be intended to result in the publication of a book-length manuscript. An individual may receive a Scholar's Award only once

Level of Study: Postdoctorate

Type: Award

Value: US $\$ 30,000$

Application Procedure: Please check at trumanlibrar yinstitute.org/research-grants/scholars-award for complete information

Closing Date: 15 December of odd-numbered years

Funding: Private

\section{For further information contact:}

Truman Library Institute, 5151 Troost Avenue, Suite 300, Kansas City, MO 64110, United States of America

Tel: $\quad$ (1) 8164001216

Fax: $\quad$ (1) 8164001213

Email: lisa.sullivan@trumanlibraryinstitute.org

Contact: Ms Lisa A. Sullivan, Grants Administrator

\section{Harry S. Truman Library Institute Research Grant}

Subjects: Research grants are intended to enable graduate students, post-doctoral scholars and other researchers to come to the Harry S. Truman Library to use its collections. Awards are to offset expenses incurred for this purpose only. Selection is made by the Institute's Committee on Research, Scholarship and Education. Funding decisions, via an application process, are based on quality, originality, significance of the project and its relationship to the existing Truman historiography, and two letters of reference. Research grants require travel to the Truman Library for study of its archival collections. One-time payments are dispersed directly and payable to the awardee upon completion of the research trip

Purpose: As part of our mission, Truman Library Institute grants are given for the purpose of supporting scholarship based on some aspect of the life and career of Harry S. Truman or of the public and foreign policy issues which were prominent during the Truman administration

Eligibility: Graduate students and post-doctoral scholars are particularly encouraged to apply, but applications from others engaged in advanced research will also be considered. Preference will be given to Truman-related projects that have application to enduring public policy 
and foreign policy issues and that have a high probability of being published or publicly disseminated in some other way. The potential contribution of a project to an applicant's development as a scholar will also be considered. The spring round of Research Grants includes one Hulston Scholarship travel grant of up to US\$2,500, to be awarded to a researcher who wishes to visit multiple research facilities — including the Truman Library - for their topic. Applicants should indicate their interest in the Harry S. Truman Library Institute Research Grant when submitting their Research Grant applications and include a detailed project budget outlining additional repositories to be consulted and how materials at those repositories fit into the larger project

Level of Study: Research

Type: Research grant

Value: Up to US\$2,500

Length of Study: 1-3 weeks

Frequency: Twice a year

Country of Study: Unrestricted

No. of awards offered: 25

Application Procedure: Competitive proposals will evidence a clear understanding of the existing research in the field and how the proposed work adds significantly to that body of literature. Applicants are expected to demonstrate both an analytical and descriptive grasp of the project and its centrality to the Truman era. Application packages must include the following: completed Research Grant application; curriculum vitae (3 pages, maximum); project description and justification (5 pages, maximum); a list of specific files the candidate expects to access at the Harry S. Truman Library and Museum; and two letters of reference from persons familiar with the applicant's scholarly work, including one from the project advisor, if candidate is a graduate or postdoctoral student. Letters must be received by the deadline and mailed or emailed directly to the Grants Administrator by the referring individual

Closing Date: 1 April and 1 October

Funding: Foundation

No. of awards given last year: 21

No. of applicants last year: 25

Additional Information: Please visit trumanlibraryinstitute. org/research-grants/research-grants for more information.

\section{For further information contact:}

5151 Troost Ave, Suite 300, Kansas City, MO 64110, United States of America

Email: lisa.sullivan@trumanlibraryinstitute.org Contact: Ms Lisa Sullivan, Grants Administrator

\section{Harvard Travellers Club}

PO Box 190, Canton, MA 02021, United States of America

Tel: $\quad$ (1) 7818210400

Fax: (1) 7818284254

Email: gpbdtes@shieldpdckdging.com

Website: www.travellersfund.org

Contact: George Bates

\section{Harvard Travellers Club Permanent Fund}

Purpose: To support research involving travel from which results can be obtained of permanent scientific and educational value

Eligibility: Must attend a university or a four-year college Level of Study: Doctorate, Graduate, Postdoctorate, Postgraduate, Predoctorate, Research, Unrestricted

Type: Grant

Value: Up to US $\$ 4,000$

Frequency: Annual

Country of Study: Worldwide

No. of awards offered: 10

Application Procedure: Please check website for all details Closing Date: Check the website

Funding: Trusts

Contributor: Club membership contributions (no major contributor)

No. of awards given last year: 2

No. of applicants last year: 10

\section{For further information contact:}

Email: Jackdeary@harvardtravellersclub.org

Contact: Mr Jack Deary, Trustee

\section{Health Canada}

Applied Research \& Analysis Directorate, Analysis \& Connectivity Branch, 15th Floor, Jeanne Mance Building, Tunney's Pasture, Ottawa, ON K1A 1B4, Canada

Tel:

(1) 6139548549

Fax: (1) 6139547363

Email: nhrdpinfo@isdicp3.hwc.ca

Website: www.hc-sc.gc.ca

Contact: Information \& Resource Officer 
The National Health Research and Development Programme (NHRDP) funds research with scientific merit to support the Federal Department of Health's mission and national health priorities, and researchers whose work will contribute to policy development and strategic planning. In general, the NHRDP funds research that relates to issues of concern to the federal government and to those that may be of concern to provincial and territorial health ministries pertaining to the health system and the promotion of population health.

\section{MSc Fellowships and PhD Fellowships}

Subjects: Disciplines closely associated with population health inquiry, such as health economics, medical sociology, epidemiology and biostatistics

Purpose: To provide support to highly qualified students who wish to undertake full-time research training leading to an MSc degree (or equivalent) or a $\mathrm{PhD}$ degree (or equivalent)

Eligibility: Open to Canadian citizens or landed immigrants of high academic standing who hold an honours Bachelor's degree or a professional degree in a health field and are already engaged in a Master's or $\mathrm{PhD}$ program

Level of Study: Postgraduate

Type: A variable number of fellowships

Value: $C \$ 19,800$ per year

Frequency: Annual

Study Establishment: at universities or affiliated institutions

Country of Study: Canada

Closing Date: 1 March

Additional Information: Prior to application, candidates should obtain a copy of the Training Awards Guide.

\section{For further information contact:}

Extramural Research Programs Directorate, Health Programs \& Services Branch, Health Canada, Ottawa, ON K1A 0S5, Canada

Tel: $\quad$ (1) 6139548549

Fax: $\quad$ (1) 6139547363

Contact: Information \& Resource Officer

\section{Health Research Board (HRB)}

Research \& Development for Health, 73 Lower Baggot Street, Dublin 2, Ireland
Tel:
(353) 12345000
Fax:
(353) 16612335
Email: hrb@hrb.ie

$\begin{array}{ll}\text { Website: } & \text { www.hrb.ie } \\ \text { Contact: } & \text { The Research Grants Manager }\end{array}$

The Health Research Board (HRB) comprises 16 members appointed by the Minister of Health, with eight of the members being nominated on the co-joint nomination of the universities and colleges. The main functions of the HRB are to promote or commission health research, to promote and conduct epidemiological research as may be appropriate at national level, to promote or commission health services research, to liaise and co-operate with other research bodies in Ireland and overseas in the promotion of relevant research and to undertake such other cognate functions as the Minister may from time to time determine.

\section{Primary Care Training and Enhancement - Physician Assistant Program}

Purpose: The purpose of the PCTE- PA Program is to increase the number of primary care physician assistants (PA), particularly in rural and underserved settings, and improve primary care training in order to strengthen access to and delivery of primary care services nationally

Eligibility: Eligible applicants must be academically affiliated PA training programs, accredited by the Accreditation Review Commission on Education for the Physician Assistant (ARC-PA). Domestic faith-based and community-based organizations, tribes and tribal organizations may apply for these funds, if otherwise eligible Level of Study: Graduate

Type: Training award

Value: US $\$ 2,000,000$

Frequency: Annual

Country of Study: Any country

Application Procedure: Links to the full announcement and online application process are available through grants.gov. check the website appropriately

Closing Date: 14 January

Funding: Private

Additional Information: Preference will be given to applicants that: 1 . Demonstrate a high rate for placing graduates in practice settings having the principal focus of serving residents of Medically Underserved Communities. 2. Demonstrate a significant increase in the rate of placing graduates in Medically Underserved Community settings over the preceding 2 years.

\section{For further information contact:}

Tel: $\quad$ (1) 3014437271

Email: SCicale@hrsa.gov 


\section{Research Leaders Awards}

Eligibility: All applications must involve a partnership with at least one health-related partner organization involved in the delivery of health and social care and/or health and social care policy. Applications should be aligned with the strategic plans of the nominating organizations, and should reflect national priorities and strategies in health and social care

Level of Study: Doctorate, Postdoctorate

Type: Award

Value: Each Research Leader Award consists of a contribution to salary support for the nominee up to the grade of Associate Professor, an attractive discretionary research support package of up to $€ 600,000$ over the period of the award, and a contribution to overhead expenses

Length of Study: A maximum of 5 years

Frequency: Annual

Country of Study: Ireland

Application Procedure: All applications must be made online using the HRB GEMS. (A link to GEMS is below.) To access the application form the nominating Higher Education Institution must provide the HRB with the contact details of their nominated Principal Investigator. The HRB will then invite the nominated candidate to initiate the application form

Closing Date: 31 March

Funding: Government

Additional Information: Please check at www.hrb.ie/ research-strategy-funding/grants-and-fellowships/hrb-grantsand-fellowships/grant/133 for more information.

\section{For further information contact:}

Email: ferrism@queensu.ca

\section{Hearst Corporation}

801 Texas Avenue, Houston, TX 77002, United States of America

Email: kenn.altine@chron.com

Website: www.hearstfellowships.com

Hearst Corporation is one of the largest diversified communications companies.

\section{Hearst Fellowships}

Subjects: Journalism

Purpose: To help develop excellent reporters, editors, photographers, designers and graphic artists
Eligibility: Open to candidates who are graduates and have experience or background in journalism or related fields

Level of Study: Professional development

Type: Fellowships

Value: Varies

Length of Study: 2 years

Frequency: Annual

Country of Study: Any country

Application Procedure: The applicants must download the application form from the website. The completed application form along with other enclosures is to be sent to Hearst Fellowships

Closing Date: 1 December

For further information contact:

Email: fellowships@hearstnp.com

\section{Heart and Stroke Foundation}

Suite 1402, 222 Queen Street, Ottawa, ON K1P 5V9, Canada

Tel: $\quad$ (1) 6135694361

Fax: (1) 6135693278

Email: research@hsf.ca

Website: www.heartandstroke.ca

The Heart and Stroke Foundation is involved in eliminating heart disease and stroke and reducing their impact through the advancement of research and its application, and advocacy for the promotion of healthy living. It is a federation of 10 provincial foundations, led and supported by a force of more than 140,000 volunteers.

\section{Canada Doctoral Research Award}

Subjects: Cardiology

Purpose: To award highly qualified graduate students enrolled in a $\mathrm{PhD}$ program, undertaking full-time research training in the cardiovascular or cerebrovascular fields Eligibility: Open to students enrolled in a $\mathrm{PhD}$ program and must be a full-time medical student

Level of Study: Doctorate, Research

Type: Research

Value: $\$ 21,000$

Country of Study: Canada

Application Procedure: Applicants must send the application form along with the transcript, essay references and a self-addressed stamped envelope

Closing Date: 1 November 


\section{For further information contact:}

Research Department, Room 9A-27, Parklawn Building, 5600

Fishers Lane, Rockville, MD 20857, United States of America

Tel: $\quad$ (1) 6135694361 ext. 327

Fax: (1) 6135693278

Email:1hodgson@hsf.ca

Contact: Lise Hodgson, Administrative Assistant

\section{Career Investigator Award}

Subjects: Cardiology

Purpose: To support established independent researchers who wish to make research their full-time career (Ontario applicants only)

Eligibility: Awards for individuals with an $\mathrm{MD}, \mathrm{PhD}$ or equivalent degree working in the field of cardiovascular and/or cerebrovascular disease who wish to make their research a full-time career. Applicants must provide proof of national recognition Level of Study: Postgraduate

Type: Scholarship

Value: Stipend C $\$ 81,500$ per year, $\$ 1,500$ per year for travel, and minimum C $\$ 48,282$ for scientific purpose

Application Procedure: Applicants must send the application form along with the transcript, essay references and a self-addressed stamped envelope and must provide proof of national recognition

Closing Date: 1 September

Contributor: Heart and Stroke Foundations of Ontario and British Columbia and the Yukon

Additional Information: For more details see website or contact the foundation.

\section{Dr Andres Petrasovits Fellowship in Cardiovascular Health Policy Research}

Subjects: Cardiology

Eligibility: Please visit the website www.hsf.ca/research/ application/index.html

Level of Study: Postgraduate

Type: Fellowship

Value: $\mathrm{C} \$ 70,000$

Length of Study: 3 years

Application Procedure: Please contact the foundation for application form

Closing Date: Check with website

\section{Grants-in-Aid of Research and Development}

Subjects: Cardiology

Purpose: To support researchers in projects of experimental nature in cardiovascular or cerebrovascular development

Eligibility: Open for full-time medical student
Level of Study: Postgraduate

Type: Grant

Value: Approx. C\$33,000,000

Frequency: Every 3 years

Application Procedure: Applicants must send the application form along with the transcript, essay references and a self-addressed stamped envelope

Closing Date: 27 August

Additional Information: Please check website for more details.

\section{Heart and Stroke Foundation of Canada Doctoral Research Award}

Subjects: Cardiology

Purpose: To support individuals enroled in a $\mathrm{PhD}$ program and undertaking full-time research training in the stroke field

Eligibility: Applicants must be Canadians studying abroad or in Canada or for foreign visitors to Canada. The fellowship is open to citizens of United States

Level of Study: Postgraduate

Type: Fellowship

Value: Varies

Country of Study: Canada

Application Procedure: Applicants must send the application form along with the transcript, essay references and a self-addressed stamped envelope

Closing Date: 1 November

For further information contact:

Heart and Stroke Foundation of Canada, 1037 Topsail Rd, Mount Pearl, NL A1N 5E9, Canada

Tel: $\quad$ (1) 6135694361 ext. 268

Fax: (1) 6135693278

Email: anguyen@hsf.ca

Contact: Ann Nguyen, Information/Project Coordinator

\section{Heart and Stroke Foundation of Canada New Investigator Research Scholarships}

Subjects: Cardiology

Eligibility: Open to candidates who possess a MD, $\mathrm{PhD}$, or equivalent degree and working in the field of cardiovascular and/or cerebrovascular disease

Level of Study: Postgraduate

Type: Scholarship

Value: Maximum C $\$ 30,000$

Application Procedure: Applicants must send the application form along with the transcript, essay references and a self-addressed stamped envelope

Closing Date: 28 August 


\section{Heart and Stroke Foundation of Canada Nursing Research Fellowships}

Subjects: Cardiology

Eligibility: Applicants must possess a Nursing degree. For master's degree candidates, the programmes must include a thesis or project requirement

Level of Study: Postgraduate

Type: Fellowship

Value: Minimum C $\$ 18,570$

Country of Study: Canada

Application Procedure: Applicants must send the application form along with the transcript, essay references and a self-addressed stamped envelope

Closing Date: 14 March

Additional Information: Please check website for more details.

\section{For further information contact:}

Research Department, 222 Queen Street, Suite 1402, Ottawa, ON K1P 5V9, Canada

Tel: $\quad$ (1) 6135694361 ext. 327

Fax: $\quad$ (1) 6135693278

Email:1hodgson@hsf.ca

Contact: Lise Hodgson, Administrative Assistant

\section{Heart and Stroke Foundation of Canada Research Fellowships}

Subjects: Cardiology

Eligibility: Applicants must possess a full-time degree for study towards an MSc or PhD

Level of Study: Postgraduate

Type: Fellowship

Value: $\mathrm{C} \$ 25,998$ (minimum) and $\mathrm{C} \$ 33,426$ (maximum)

Country of Study: Canada

Application Procedure: Applicants must send the application form along with the transcript, essay references and a self-addressed stamped envelope

Closing Date: 1 November

\section{Heart Research United Kingdom}

Suite 12D, Joseph's Well, LS3 1AB, Leeds, United Kingdom

Tel: $\quad$ (44) 1132347474

Fax: (44) 1132976208

Email: mail@heartresearch.org.uk

Website: www.heartresearch.org.uk

Contact: Helen Wilson, Senior Research Officer
Heart Research United Kingdom funds pioneering medical research into the prevention, treatment and cure of heart disease. Heart Research United Kingdom is a visionary charity leading the way in funding ground-breaking, innovative medical research projects at the cutting edge of science into the prevention, treatment and cure of heart disease. There is a strong emphasis on clinical and surgical projects and young researchers. Heart Research United Kingdom encourages and supports original health lifestyle initiatives exploring novel ways of preventing heart disease in all sectors of the community.

\section{Heart Research United Kingdom Translational Research Project Grants}

Subjects: Translational research projects that convert fundamental research into clinical benefits

Purpose: To support ground-breaking, innovative medical research into prevention, treatment and cure of heart disease and related conditions

Eligibility: Graduates or those holding a suitable professional qualification. Research must be carried out in the United Kingdom at a university, hospital or other recognized research institution

Level of Study: Research, Unrestricted

Type: Project grant

Value: Up to $£ 150,000$

Length of Study: Up to 3 years

Frequency: Annual

Study Establishment: Centres of health and educational establishments

Country of Study: United Kingdom

No. of awards offered: 45

Application Procedure: Information and application forms available at heartresearch.org.uk/grants/translationalresearch-project-trp-grants

Closing Date: 1 June

Funding: Private, Corporation, Foundation, Trusts, Individuals

Contributor: Voluntary funding from supporters and grantmaking trusts

No. of awards given last year: 6

No. of applicants last year: 45

Additional Information: Grants are for research which efficiently transfers innovative discoveries into practical tools to prevent, diagnose and treat cardiovascular disease.

\section{For further information contact:}

Tel: (44) 1132347474

Email: grants@heartresearch.org.uk 


\section{Hellenic Pasteur Institute}

Vas Sofias Avenue 127, GRC-11521 Athens Greece

Tel: $\quad$ (30) 16478800

Fax: (30) 16423498

Website: www.pasteur.gr

Contact: Dr S Tzartos

\section{W.D.E. Coulson \& Toni M. Cross Aegean Exchange Program}

Purpose: The purpose of these fellowships is to provide an opportunity for Greek scholars to meet with their Turkish colleagues, and to pursue research interests in the museum, archive, and library collections and at the sites and monuments of Turkey

Eligibility: The library at ARIT-Istanbul includes approximately 14,000 volumes and covers the Byzantine, Ottoman, and modern Turkish periods. Archives, libraries, sites, and museums in Turkey provide resources for research into many fields of study and geographical areas

Level of Study: Postdoctorate

Type: Fellowship

Length of Study: From two weeks to two months

Frequency: Annual

Country of Study: Any country

Application Procedure: 1. Stipend of US\$250 is required. 2. Submit "Associate Membership with Fellowship" application online. 3. The application should include a curriculum vitae, statement of the project to be pursued during the period of grant (up to three pages, single-spaced in length), two letters of reference from scholars in the field commenting on the value and feasibility of the project

Funding: Private

Additional Information: ascsa.submittable.com/submit/ 115754/elizabeth-a-whitehead-distinguished-scholars-applica tion-form

\section{Help Musicians United Kingdom}

7-11 Britannia Street, WC1X 9JS, London, United Kingdom

Tel: $\quad$ (44) 2072399100

Fax: $\quad$ (44) 2077138942

Email:_creative@helpmusicians.org.uk

Website: www.helpmusicians.org.uk

Contact: Ms Claire Gevaux, Director of Giring
Help Musicians United Kingdom is a unique charity which provides essential help to musicians of all ages and genres. We support music professionals throughout their working lives when a crisis such as an accident or illness can have a devastating impact, and in later life, with the challenges that growing older can bring. We support talented, financially needy young musicians to enable them to fully develop their creativity and musical potential, ensuring they enter the profession with the best prospects of success. We are also working in partnership with a number of organizations across the United Kingdom who provide outstanding opportunities for musicians. We rely on donations and the generosity of music lovers and musicians to enable our vital wok to continue.

\section{Career Development Bursaries}

Subjects: These awards are open to emerging artists aged $21-35$ to fund an important development opportunity, project or programme of activity that will have a lasting impact on their professional career

Purpose: To help musicians looking for opportunities that will benefit their professional development

Eligibility: Applicants must be British or Irish or have lived in the United Kingdom for at least 3 consecutive years

Type: Award

Value: $£ 500-2,000$

Country of Study: Any country

No. of awards offered: 108

Application Procedure: A written description of the project must be provided with a budget, a reference and a recording demonstrating composition and/or performance

Closing Date: 30 February

No. of awards given last year: 18

No. of applicants last year: 108

Additional Information: Please check website www. helpmusicians.org.uk/eea

\section{For further information contact:}

Email: info@handsupfortrad.co.uk

\section{Postgraduate Awards}

Subjects: Our postgraduate awards are only open to students who wish to study performance at the following conservatoires or performance institutions: 1. Arts Educational Schools. 2. Guildford School of Acting. 3. Guildhall School of Music and Drama. 4. Leeds College of Music. 5. London School of Musical Theatre. 6. Mountview Academy. 7. National Opera Studio. 8. Royal Academy of 
Music. 9. Royal Birmingham Conservatoire. 10. Royal Central School of Speech and Drama. 11. Royal College of Music. 12. Royal Conservatoire of Scotland. 13. Royal Northern College of Music. 14. Royal Welsh College of Music and Drama. 15. Trinity Laban Conservatoire of Music and Dance. 16. Urdang Academy. 17. Wales International Academy of Voice. 18. Musical Theatre only. 19. Opera courses only

Purpose: Help Musicians United Kingdom's postgraduate awards offer support to students who wish to complete their studies at the leading UK conservatoires and performing arts colleges. The charity has been making awards to postgraduate music students of between $£ 1,000$ and $£ 5,000$ since the 1970s. Previous winners of these awards include trumpeter Alison Balsom OBE, percussionist Dame Evelyn Glennie, violinist Clio Gould, cellist Guy Johnston, violinist Tasmin Little OBE and guitarist Miloš Karadaglic. The Postgraduate Awards were previously run on a nomination basis where Heads of Departments at select conservatoires and performing colleges put forward students who qualified for the grant. However, HMUK is now reviewing how accessible and inclusive the Programme is to ensure that any potential barriers there may be in applying for funding are removed. The new open and direct application process also aims to alleviate some of the administrative burden on the Heads of Department and empower the students to take control of their futures

Level of Study: Postgraduate

Type: Award

Value: Up to $£ 5,000$

Length of Study: Annual Awards

Frequency: Annual

Country of Study: United Kingdom

No. of awards offered: 200

Application Procedure: Must have lived in United Kingdom for 3 consecutive years by Postgraduate start date. Applications made via online application form

Closing Date: February of each year

Funding: Private

Contributor: Help Musicians United Kingdom

No. of awards given last year: 125

No. of applicants last year: 200

Additional Information: Applications for musical theatre, opera, répétiteurs and popular music students open April of each year. (i.e. Mmus, MA, PGDip, Artist Diploma) Have lived in the United Kingdom for at least 3 consecutive years at the start of the academic year in which they will be supported by the award Be in financial need Demonstrate that they have the musical potential and ambition to create a successful and sustainable career within the music industry HMUK strongly encourages applications from students from underrepresented backgrounds, including those from BAME (Black, Asian and Minority Ethnic) backgrounds, D/deaf and disabled people; and those from lower socio-economic groups. Through our Postgraduate Awards, we are unable to fund: Non-music performance degrees such as composition, music technology, music education, music therapy, arts administration and music business Undergraduate courses PhDs, MPhil, DMus, Doctorates Study from the previous academic year

\section{For further information contact:}

Tel: $\quad$ (44) 2072399119

Email: creative@helpmusicians.org.uk

\section{Sybil Tutton Awards}

Subjects: Help Musicians United Kingdom offers Sybil Tutton Awards to outstandingly talented singers on full-time postgraduate opera courses to help with study costs. A special Richard Van Allen Award may be offered to a suitably outstanding male singer

Purpose: To assist students on advanced postgraduate opera courses

Eligibility: Nominees must be British or Irish or have lived in the United Kingdom for at least five consecutive years at the closing date

Type: Award

Value: $£ 1,000-5,000$

Frequency: Annual

Country of Study: Any country

Application Procedure: Application is by nomination only from head of voice at the United Kingdom conservatoires and the National Opera Studio

Closing Date: May

For further information contact:

Email: awards@helpmusicians.org.uk

\section{Henry Moore Institute}

The Headrow, LS1 3AH, Leeds, United Kingdom

Tel:

$$
\text { (44) } 1132467467
$$

Email: kirstie@henry-moore.org

Website: www.henry-moore.org

Contact: Kirstie Gregory, Research Programme Assistant

The Henry Moore Institute is a world-recognized centre for the study of sculpture in the heart of needs an award-winning exhibitions venue, research centre, library and sculpture archive. The institute hosts exhibitions, conferences and 
lectures, as well as developing research to expand the understanding and scholarship of historical and contemporary sculpture.

\section{Henry Moore Institute Research Fellowships}

Subjects: Sculpture, both historical and contemporary Purpose: To enable scholars to use the Institute's facilities, which include the sculpture collection, library, archive and slide library, to assist them in researching their particular field Eligibility: There are no restrictions

Level of Study: Doctorate, Postdoctorate, Postgraduate, Research

Type: Fellowship

Value: Accommodation, travel and daily living expenses

Length of Study: 1 month

Frequency: Annual

Study Establishment: The Henry Moore Institute

Country of Study: United Kingdom

No. of awards offered: 80

Application Procedure: Applicants must send a letter of application, a proposal (maximum 1,000 words) and a curriculum vitae. Visit the website

Closing Date: 12 January

Funding: Foundation

Contributor: The Henry Moore Foundation

No. of awards given last year: 4

No. of applicants last year: 80

For further information contact:

Email: kirstie@henry-moore.org

Contact: Kirstie Gregory

\section{Henry Moore Institute Senior Fellowships}

Subjects: Any aspect of sculpture. Fellows are asked to make a small contribution to the research programme in Leeds in the form of a talk or a seminar

Purpose: Senior fellowships are intended to give established scholars (working on any aspect of sculpture) time and space to develop a research project free from their usual work commitments

Level of Study: Doctorate, Postdoctorate

Type: Fellowship

Value: Fellowships provide accommodation, travel expenses, and a per diem

Length of Study: 3-6 weeks

Frequency: Annual

Study Establishment: Henry Moore Institute

Country of Study: United Kingdom
No. of awards offered: 15

Application Procedure: Full details are available from the website www.henry-moore.ac.uk. Applicants can also contact the institute at its address for details. An applicant must send a curriculum vitae and a proposal along with his or her letter of application

Closing Date: 12 January

Funding: Foundation

Contributor: Henry Moore Foundation

No. of awards given last year: 1

No. of applicants last year: 15

Additional Information: Research fellowships are also available. The institute offers the possibility of presenting finished research in published form as a seminar or as a small exhibition

\section{For further information contact:}

Tel:

$$
\text { (44) } 1132467467
$$

Email: kirstie@henry-moore.org

Contact: Kirstie Gregory, Research Programme Assistant

\section{Herb Society of America, Inc.}

9019 Kirtland Chardon Road, Kirtland, OH 44094, United States of America

Tel: $\quad$ (1) 4402560514

Fax: (1) 4402560541

Email: herbs@herbsociety.org

Website: www.herbsociety.org

Contact: Ms Michelle Milks, Office Administrator

The aim of the Herb Society of America Inc. is to promote the knowledge, use and delight of herbs through educational programmes, research and sharing the experience of its members with the community.

\section{Herb Society of America Research Grant}

Subjects: Herbal projects

Purpose: To further the knowledge and use of herbs and to contribute the results of study and research to the records of horticulture, science, literature, history, art or economics Eligibility: Open to persons with a proposed programme of scientific, academic or artistic investigation of herbal plants

Level of Study: Unrestricted 
Value: Up to US $\$ 5,000$

Length of Study: Up to 1 year

Frequency: Annual

Country of Study: Any country

Application Procedure: Applicants must submit an application clearly defining all their research in 500 words or less and a proposed budget with specific budget items listed. Requests for funds will not be considered unless accompanied by five copies of the application form and proposal. The application must be submitted in electronic form via email to herbs@herbsociety.org

Closing Date: 31 January

Contributor: Members

Additional Information: Finalists will be interviewed. In order to complete the application, use the below link. herbsocietyorg. presencehost.net/support/grants-scholarships/applicationfor-the-hsa-research-grant.html

\section{For further information contact:}

Email: herbs@herbsociety.org

\section{Heriot-Watt University}

Postgraduate Admissions Office, EH14 4AS, Edinburgh, United Kingdom

\section{Tel: $\quad$ (44) 1314495111}

Email: edu.liaison@hw.ac.uk

Website: www.hw.ac.uk

Contact: Fiona Watt, Wider Access Assistant

Heriot-Watt University, one of the oldest higher education institutions in the United Kingdom, is Scotland's most international university. Our six academic schools and two postgraduate institutes offer research opportunities and postgraduate taught programmes in science and engineering, business, languages and design. We disburse over $£ 6 \mathrm{M}$ in fee and stipend scholarships annually.

\section{Mexican Scholarships}

Subjects: Science, engineering and technology

Purpose: Financial assistance for Mexican students in science, engineering and technology

Eligibility: Mexican citizens

Level of Study: Postgraduate

Type: Scholarship

Value: Tuition fees and living costs
Frequency: Annual

Study Establishment: Heriot-Watt University

Country of Study: Scotland

Application Procedure: Contact Bob Tuttle

Funding: Government

Contributor: Heriot-Watt and CONACYT (Mexican

National Council for Science and Technology)

\section{For further information contact:}

Tel: (44) 1314513746

Email: b.tuttle@hw.ac.uk

\section{Music Scholarships}

Subjects: All subjects

Purpose: To support musicians in obtaining a postgraduate qualification whilst developing their musical skills

Eligibility: All instrumentalists and vocalists who have been accepted for a course. The following criteria are taken into consideration: musical ability and potential, proof of exam results and membership of orchestras or choirs; a reference from your last vocal or instrumental teacher; in the case of the Archer Music Scholarships, a personal statement is also required; auditions will be held during Semester 1

Level of Study: Postgraduate, Research

Type: Scholarship

Value: Free music tuition up to value of $£ 400$ per year

Length of Study: 1 year

Frequency: Annual

Study Establishment: Heriot-Watt University

Country of Study: Scotland

Application Procedure: For an application form or more information please contact Steve King MBE, Director of Music

Additional Information: There will be a music scholar's concert in HWU in March each year at which all music scholars are all expected to participate.

\section{For further information contact:}

Tel: (44) 1314513705

Email: s.king@hw.ac.uk

Contact: Steve King MBE, Director of Music

\section{Overseas Research Students Awards Scheme (ORSAS)}

Purpose: Assist international postgraduate research students with payment of tuition fees 
Eligibility: Non-European Union research applicants

Level of Study: Research

Type: Scholarship

Length of Study: 3 years

Frequency: Annual

Study Establishment: Heriot-Watt University

Country of Study: Scotland

Application Procedure: Apply to School of Study

Closing Date: 30 November

Contributor: Heriot-Watt University

Additional Information: Successful applicants usually receive James Watt Scholarships for the remainder of their fees plus a maintenance contribution.

\section{For further information contact:}

Email: pgadmissions@glasgow.ac.uk

\section{Higher \& Education South Africa}

\section{Africa: Mwalimu Julius Nyerere African Union Scholarship}

Purpose: Mwalimu Julius Nyerere African Union Scholarship is intended to enable young Africans to study at reputable African universities with a binding agreement that scholarship beneficiaries will work in any African country for at least the same duration of the scholarship period after graduation. The scholarship aims to provide an opportunity to enhance knowledge, professional skills and capacity of refugees and displaced people, in order to streamline their integration to contribute towards sustainable development in Africa

Eligibility: 1. Applicants must be a citizen of an African Union Member State. 2. Must be a formally registered refugee/displaced person with a UNHCR registration number or be able to demonstrate confirmed refugee status in an African Union Member State. 3. Must be under the age of thirty five (35) years. 4. Must be a holder of a Bachelor's degree in the relevant field, at least at the level of Upper Second class Honours. The degree must be from a recognised university. 5. Must have demonstrated outstanding academic achievement as evidenced by academic transcripts, and academic awards if any. 6. Have proof of admission to undertake a full time Master's programme in a recognized university in an African Union Member State. 7. Be willing to commit to work in an African Union Member State on completion of studies for at least three (3) years

Level of Study: Postgraduate

Type: Scholarship
Value: Stipend to the value of US\$500 monthly to cover accommodation, meals, utilities, local transport and medication, Travel allowance: once-off US\$250, US\$350 to assist with shipping and other terminal expenses, Computer allowance: US $\$ 1,000$

Frequency: Annual

Country of Study: South Africa

Application Procedure: Apply online: www.edu-au.org/ scholarshipg

Closing Date: 30 April

Funding: Foundation

\section{For further information contact:}

Department of Human Resources, Science and Technology, African Union Commission, P O Box 3243, Addis Ababa, Ethiopia, Eastern Africa

Tel: (251) 115517700

Fax: (251) 115517844

Email: internationalscholarships@dhet.gov.za

\section{Africa: Next Einstein Forum (NEF) Fellows Programme}

Purpose: The Next Einstein Forum (NEF) is an initiative of the African Institute for Mathematical Sciences (AIMS) in partnership with the Robert Bosch Stiftung. The NEF is a platform that connects science, society and policy in Africa and the rest of the world - with the goal to leverage science for human development globally. The Fellows Programme consists of Africa's most brilliant young scientists that the NEF showcases on the global stage. The Programme provides Fellows with the opportunity to present their research and draw upon the vast networks of NEF members and participants for support, connections and advice to advance their work

Eligibility: 1. Africans from around the world - including those who currently reside in the Diaspora. 2. Hold a passport from an African country. 3. Hold a PhD in a field of science, Technology, Engineering, Mathematics or the social sciences. 4. Have a demonstrated track record of research/findings that have global impact. 5. You are passionate about raising Africa's profile in STEM globally. 6. Able to clearly present their work to an audience in English or French

Level of Study: Postgraduate

Type: Fellowship

Frequency: Annual

Country of Study: South Africa

Closing Date: 27 January

Funding: Foundation 


\section{For further information contact:}

NEF Secretariat, c/o AIMS-NEI 590 KG ST Gasabo, Kigali, Rwanda

Email: info@nef.org

\section{Austria: Erasmus+ Master in Research and Innovation in Higher Education (MARIHE) Programme}

Purpose: The Master in Research and Innovation in Higher Education (MARIHE) is supported by the Erasmus+ Programme of the European Union (EU) under the action of an Erasmus Mundus Joint Master Degree (EMJMD)

Eligibility: 1. Must hold a first university degree, this should be at least a Bachelor degree issued by a university, quantified as three years of studies corresponding. 2. Show a strong motivation and interest. 3. Have sufficient knowledge of English for academic purposes

Level of Study: Postgraduate

Type: Grant

Frequency: Annual

Country of Study: South Africa

Application Procedure: Apply online: www.marihe.eu/ how-to-apply/application-process-and-timetable

Closing Date: 5 December

Funding: Private

For further information contact:

Email: marihe@donau-uni.ac.at

\section{Azerbaijan: Non-Aligned Movement (NAM) Scholarship}

Purpose: The Government of the Republic of Azerbaijan is offering scholarships for Bachelor's, Master's and Doctoral programmes to the citizens of Non-Aligned Movement (NAM) countries (including South Africa)

Eligibility: 1. Citizen of Non-Aligned Movement (NAM) countries (this includes South Africa). 2. For undergraduate programmes applicants must be younger than 25 years old. 3 . For Master's programmes applicants must be younger than 30 years old. 4 . For doctoral programmes applicants must be younger than 35 years old

Level of Study: Postgraduate

Type: Scholarship

Value: $800 \mathrm{AZN}$

Frequency: Annual

Country of Study: South Africa
Application Procedure: Apply: www.internationalschol arships.dhet.gov.za/Application\%20form.pdf

Closing Date: 10 February

Funding: Foundation

For further information contact:

Email: internationalscholarships@dhet.gov.za

\section{Brunei Darussalam: Government of Brunei Darussalam Scholarship}

Purpose: The Brunei Darussalam Ministry of Foreign Affairs invites applications for the Government of Brunei Darussalam Scholarship. The scholarship is tenable at higher education institutions in Brunei Darussalam and provides applicants with an opportunity to pursue Diploma, Bachelor's and Master's degrees

Eligibility: 1. Citizens of, but not limited to the Association of Southeast Asian Nations (ASEAN), Commonwealth and Organisation of Islamic Cooperation (OIC) member countries (this includes South Africa). 2. Applicants should be nominated by their Government. 3. Applicants must be in good health and have a strong academic record. 4. Applicants must be between the ages of 18-35 for Undergraduate and Diploma programmes and must not exceed 35 for Master's studies, by 31 July. 5. Candidates must be prepared to fund any costs not covered by the scholarship

Level of Study: Postgraduate

Type: Scholarship

Frequency: Annual

Country of Study: South Africa

Application Procedure: Apply online: www.ubd.edu.bn/ admission/scholarships.html

Closing Date: 28 February

Funding: Foundation

\section{For further information contact:}

Email: internationalscholarships@dhet.gov.za

\section{China: Chinese Government Scholarship}

Purpose: The Chinese Government is offering scholarships for South African students to study at Chinese institutions. The Department of Higher Education and Training is responsible for nominations

Eligibility: Listed below are the eligibility factors for the scholarship: 1. South African citizens in good health (medical check will be required for successful applicants). 2. Strong academic record with a minimum $65 \%$ average in previous studies. 3. Demonstrated interest in China and 
commitment to the development of South Africa. 4. Applications in all fields of study except medicine will be considered. 5. Preference will be given to postgraduate applicants, previously disadvantaged applicants and applications in the following fields. The scholarship is offered for undergraduate (Bachelors) in the identified scarce skills, postgraduate (Masters or $\mathrm{PhD}$ ) or non-degree Chinese language studies. Bachelor's degree scholarships are taught in Chinese and will only be awarded to applicants who already have the required level of Chinese proficiency (HSK 5 or above). Preference is given to applications for postgraduate studies

Level of Study: Postgraduate

Type: Scholarship

Frequency: Annual

Country of Study: South Africa

Application Procedure: Apply online: http:/www. campuschina.org/universities/index.html

Closing Date: 15 March

Funding: Foundation

\section{For further information contact:}

Level 13, Building A3 No. 9 Chegongzhuang St, Dong Wu Yuan, Xicheng Qu, Beijing Shi, CN 100738, China

Email: internationalscholarships@dhet.gov.za

\section{China: One Belt One Road Scholarship}

Purpose: Peking University Guanghua School of Management is offering One Belt One Road Scholarship to pursue an MBA programme at Peking University. The International MBA programme is a full-time (2 years) English-taught programme

Eligibility: 1. Applicants must hold a non-Chinese citizenship and be citizens from Belt and Road Initiative (BRI) countries. 2. Must hold a Bachelor's degree equivalent to a Bachelor's degree in China. 3. Must have two or more years of relevant full-time work experience. 4. Must obtain a competitive score from the Guanghua MBA entrance exam. 5. Must have leadership quality

Level of Study: Postgraduate

Type: Scholarship

Value: Accommodation subsidy (4,000 RMB/person/ month), Living allowance (3,000 RMB/person/month), edical insurance fee (800 RMB/person/year), Application fee of 800RMB will be waived

Length of Study: 2 year

Frequency: Annual

Country of Study: South Africa

Application Procedure: Apply online: applymba.pku.edu. $\mathrm{cn} /$ The One Belt One Road Scholarship will not only provide the opportunity to study at Peking University which is one of the most prestigious universities in China, and is ranked \#1 in China and \#2 in the Asia-Pacific region by Times Higher Education World University Rankings, but also a chance to become an expert in China affairs and gain a solid foothold in the China market

Closing Date: Round 3: 28 February Round 4: 15 April Enrollment deadline: Early September

Funding: Private

For further information contact:

Apply online: applymba.pku.edu.cn/

Tel: $\quad$ (86) 15010656075

Email: yul@gsm.pku.edu.cn

\section{China: Renmin University Master of Contemporary Chinese Studies Scholarship}

Subjects: Chinese Politics, Chinese Economy, Chinese Culture, Chinese Law

Purpose: The Silk Road School at the Renmin University of China (Suzhou) offers scholarships to foreign students who wish to pursue a Master of Contemporary Chinese studies at Renmin University of China (Suzhou)

Eligibility: 1. Be foreign citizens who have interest in Belt and Road Initiative (BRI) and Chinese culture. 2. Have the ability to speak, read and write English at an equivalent score of IELTS 6.5 or TOEFL 90

Level of Study: Postgraduate

Type: Scholarship

Frequency: Annual

Country of Study: South Africa

Application Procedure: Apply online: www.rdcy.org/ displaynewsen.php? $\mathrm{id}=45928$

Closing Date: 10 June

Funding: Foundation

\section{For further information contact:}

Tel: (86) 1062516305

Email: srsruc@ruc.edu.cn

\section{Embassy of France in South Africa Master Scholarship Programme}

Purpose: The Embassy of France invites students who wish to continue their tertiary education at Master level in France for the academic year September apply for its scholarship programme 
Eligibility: 1. Citizenship of South Africa or Lesotho. 2. Bachelor's or Honour's graduate (depending on the academic year to enrol for), completed or to be completed by the time the student would depart for France. 3. Acceptance from three selected French institutions of the candidate's choice. Students should apply for admission to these universities concurrently to the bursary application (admission letters or at least correspondence with the institutions will be required for complete applications). 4. Maximum academic fees (administration and tuition fees combined) financed with a full scholarship: 5,000€. For academic fees higher than $5,000 €$ co-financing options must be provided (personal savings and/or enterprise sponsorship). 5. Maximum academic fees (administration and tuition fees combined) financed with a full scholarship: 5,000€. For academic fees higher than $5,000 €$ co-financing options must be provided (personal savings and/or enterprise sponsorship). 6. No knowledge of French language required, depending on the availability of study course in English. Courses relating to the French Language (i.e. translation, interpreting or French language teaching) must follow a different application process

Level of Study: Postgraduate

Type: Scholarship

Value: $€ 5,000$

Length of Study: 1 year

Frequency: Annual

Country of Study: Any country

Closing Date: 15 March

Funding: Foundation

\section{For further information contact:}

Email: audrey.delattre@diplomatie.gouv.fr

\section{Embassy of France in South Africa PhD Grants}

Purpose: The French Embassy scholarship programme offers grants to facilitate in the international academic and scientific mobility of South African and non-South African researchers to French Higher Education institutions. The programme offers the opportunity for doctoral students to integrate into French establishments for specified time periods in order to participate in collaborative research as part of their doctoral research project

Eligibility: 1. Registration for a $\mathrm{PhD}$ at a South African university. 2. A hosting agreement from the French institution. 3. Support letters from your South African supervisor and French co-supervisor, supporting the proposed research project. 4. Applications from all academic disciplines will be considered. 5. No knowledge of French language required, provided the student will be able to conduct research in English
Level of Study: Postgraduate

Type: Scholarship

Value: $€ 1,065$

Frequency: Annual

Country of Study: Any country

Funding: Foundation

\section{For further information contact:}

Tel: (27) 123436563

Email: pretoria@campusfrance.org

\section{France: French Embassy and Saint-Gobain Master Scholarship}

Subjects: Finance, Supply chain, Construction (architectural) and Marketing

Purpose: Saint-Gobain and the Embassy of France in South Africa are offering scholarships to South Africans and Basotho graduates to pursue a Master's degree in Business studies or Engineering at public French universities

Level of Study: Postgraduate

Type: Scholarship

Value: $€ 767$ and annual tuition fees $(€ 3,770)$ at public universities

Frequency: Annual

Country of Study: Any country

Application Procedure: Apply online: www.southafrica. campusfrance.org/page/campusfrance-south-africa-office

Closing Date: 30 March

Funding: Private

Additional Information: Contacts could be further established with the below link. www.southafrica.campusfrance.org/page/ campusfrance-south-africa-office

\section{For further information contact:}

Email: pretoria.bourses@campusfrance.org

\section{France: French Embassy Masters and PhD Scholarship Programme}

Purpose: The Embassy of France is offering scholarships to postgraduate South Africans who wish to pursue Master's and Doctoral studies at French higher education institutions

Eligibility: 1. Be a citizen and resident of South Africa. 2. Apply for university admission at three French universities concurrent to the scholarship application (admission letters or at least correspondence with the institutions will be required). Applications to French public universities are recommended since they have French government subsidised fees. 3. French proficiency is not required, provided they are pursuing a study 
course in English and have the ability to conduct research in English. 4. Courses relating to French language studies (i.e. translation, interpreting or French language teaching) must follow a different application process by contacting Audrey Delattre

Level of Study: Postgraduate

Type: Scholarship

Frequency: Annual

Country of Study: South Africa

Application Procedure: Apply online: www.southafrica. campusfrance.org/sites/locaux/files/PhD $\% 20$ French $\% 20 \mathrm{Emb}$ assy\%20application\%20form\%202019.pdf

Closing Date: 15 March

Funding: Foundation

For further information contact:

Email: pretoria@campusfrance.org

\section{France: ISAE-SUPAERO Scholarship Programmes}

Purpose: The ISAE-SUPAERO Institute offers a wide range of science and engineering degree programs with a number of scholarships offered through industry support and the SUPAERO Foundation for pursuing studies towards a Master of Science in Aerospace Engineering degree. These scholarships cover tuition and part of living expenses Eligibility: Applicants who hold a Bachelor's degree or the equivalent in Mechanical Engineering, Mechatronics, Aerospace, Electronics, Electrical Systems, Telecommunications or a French licence in Science and Engineering

Level of Study: Postgraduate

Type: Scholarship

Value: Tuition fees: $€ 10,600$, Living expenses: $€ 8,000$ to $€ 10,000$

Frequency: Annual

Country of Study: South Africa

Application Procedure: Apply online: www.isae-supaero.fr/ en/academics/master-s-degree-msc/admissions/

Closing Date: Please check the links for the deadlines for the next academic year

Funding: Foundation

For further information contact:

Tel: $\quad$ (33) 561338027

Email: philippe.galaup@isae-supaero.fr

\section{Hungary: Stipendium Hungaricum for South Africa}

Purpose: The Hungarian Government is offering 100 scholarships to South African students to study at participating public university in Hungary. All courses available for South Africans are taught in English

Eligibility: 1. Be a South African citizen in good health. 2. Have a strong academic record. 3. An interest in studying in Hungary and demonstrated commitment to the development of South Africa. 4. Meet the entry criteria for their selected programme in Hungary. 5. Meet the minimum academic requirement for entry into a similar programme at a South African university

Level of Study: Postgraduate

Type: Grant

Frequency: Annual

Country of Study: South Africa

Application Procedure: Apply online: apply.stipendium hungaricum.hu/

Closing Date: 15 January

Funding: Foundation

\section{For further information contact:}

Email: HungaryScholarshipApplications2019@dhet. gov.za

\section{India: Export-Import Bank of India BRICS Economic Research Award}

Purpose: The Export-Import Bank of India (EXIM) has instituted the Export-Import Bank of India BRICS Economic Research Award. The award aims to encourage and stimulate advanced research on economics related topics of relevance to the member nations of Brazil Russia India China South Africa (BRICS). The EXIM Bank of India invites South African research scholars to apply for the Exim Bank of India BRICS Economic Research Award

Eligibility: Check online: www.eximbankindia.in/Assets/ pdf/award/EXIM\%20Bank\%20BRICS\%20Economic\%20 Research\%20Award-\%20Guidelines\%20(English)\%2015. 04.2019.pdf

Level of Study: Postgraduate

Type: Award

Value: US\$22 000

Frequency: Annual

Country of Study: South Africa

Application Procedure: Apply online: www.eximbankindia. in/awards

Closing Date: 15 April

Funding: Foundation

\section{For further information contact:}

Tel: $\quad$ (91) 2222172701

Email: rag@eximbankindia.in 


\section{Indonesia: Kemitraan Negara Berkembang (Developing Countries Partnership) Scholarship}

Purpose: The Kemitraan Negara Berkembang (KNB) Scholarship was first introduced by the Ministry of Education and Culture to embrace higher education globalization by providing financial assistance (scholarship) to the selected Indonesian Universities, to recruit potential international students to acquire Master's degrees in those universities. The KNB Scholarship program has expanded and is now offered to potential students from developing countries to acquire Bachelor's or Master's degrees at the prestigious universities in Indonesia. The Indonesian Government is offering 140 Master's and five Bachelor's degrees scholarships. All programmes are delivered in Bahasa Indonesia

Eligibility: 1. Applicants must not be older than 35 years of age. 2. Applicants must hold a Bachelor degree (Master's degree holder is not eligible to apply). 3. Applicants must have a TOEFL (or other certified English Proficiency) score of 500. 4. Applicants must be between the ages of 18-35 for Undergraduate and Diploma programmes

Level of Study: Postgraduate

Type: Scholarship

Frequency: Annual

Country of Study: South Africa

Application Procedure: Apply online: www.knb.ristekdikti. go.id

Closing Date: 30 April

Funding: Foundation

\section{For further information contact:}

The Information and Socio-Cultural Section, The Embassy of the Republic of Indonesia, 949 Francis Baard Street, Arcardia 0083, South Africa

Tel: (27) 123423350

Email: info@indonesia-pretoria.org.za

\section{Ireland: Kader Asmal Fellowship Programme}

Purpose: The Embassy of Ireland in South Africa in partnership with the Department of Higher Education and Training and the Canon Collins Trust invites applications for scholarships for one-year Master's degree study in Ireland commencing in September

Eligibility: 1. Be a South African citizen. 2. Have achieved the necessary standard to be accepted onto a postgraduate course in an institute of higher education in Ireland. 3. Be seeking funding for a full-time postgraduate programme in one of the above listed subject areas. 4. Be able to take up fellowship in the academic year. 5. Not have already applied for a course at an institution in Ireland - if you have already been admitted to a university you are not eligible

Level of Study: Postgraduate

Type: Fellowships, operating grants

Frequency: Annual

Country of Study: South Africa

Application Procedure: Apply online: www.canoncollins. org.uk/apply/scholarship/kader-asmal-fellowship

Closing Date: 31 December

Funding: Private

\section{For further information contact:}

Email: Rose.Machobane@dfa.ie

\section{Japan: MEXT Scholarships}

Purpose: The Japanese Ministry of Education, Culture, Sports, Science, and Technology (MEXT) offers scholarships to foreign students who wish to study at Japanese universities under the Japanese Government Scholarship Program

Eligibility: see website: www.za.emb-japan.go.jp/itpr_en/ MEXT_Scholarship.html

Level of Study: Postgraduate

Type: Scholarship

Frequency: Annual

Country of Study: South Africa

Application Procedure: Applications must be couriered or be hand delivered and addressed to: Cultural Section of the Embassy of Japan in South Africa: 259 Baines Street, Groenkloof, Pretoria, 0181

Closing Date: 8 June

Funding: Foundation

\section{For further information contact:}

Cultural Section of the Embassy of Japan in South Africa, 259 Baines Street, Groenkloof, Pretoria 0181, South Africa

Email: ryan.keet@pr.mofa.go.jp

\section{Jordan: Talal Abu-Ghazaleh University College for Innovation Scholarship}

Purpose: Talal Abu-Ghazaleh University College for Innovation (TAGUCI) is offering a scholarship for a South African student who wishes to pursue a Master of Business Administration (MBA) degree at TAGUCI. Registration is now open for the semester

Eligibility: 1. Applicants must submit official Bachelor's degree transcripts and certificate, stamped by the Ministry of Higher Education and Scientific Research in Jordan. 2. English Language Equivalency exam mark of $65 \%$. 
3. Minimum of two years of work experience. 4. Written essay of up to 3,000 words. 5. Candidates must be prepared to fund any costs not covered by the scholarship

Level of Study: Postgraduate

Type: Scholarship

Frequency: Annual

Country of Study: Any country

Application Procedure: Apply online: www.taguci.edu.jo/

RegistrationForm.aspx

Closing Date: 28 February

Funding: Foundation

\section{For further information contact:}

Tel: $\quad$ (962) 65100900

Email: info@taguci.edu.jo

\section{Mauritius: Mauritius-Africa Scholarship Scheme}

Purpose: As part of a commitment to promote capacitybuilding at high level across thecontinent, the Government of Mauritius is awarding scholarships to deserving students who are resident citizens of member states of the African Union or of African Commonwealth countries for full-time, on-campus undergraduate and postgraduate programmes tenable in public Higher Education Institutions (HEIs) in Mauritius

Eligibility: 1. South African citizens in good health and with a strong academic record. 2. Candidates must have an interest in studying in Mauritius and demonstrate a commitment to the development of South Africa. 3. Candidates must be available to study in Mauritius at the start of their academic programme. 4. All applicants must meet the entry criteria for their selected programme in Mauritius. 5. Have an interest in studying in Mauritius and demonstrate a commitment to the development of South Africa. 6. All applicants must meet the minimum academic requirement for entry into a similar programme at a South African university. 7. All candidates must have proficiency in English. 8. Not be in receipt of a scholarship from any other public source in Mauritius

Level of Study: Postgraduate

Type: Scholarship

Value: Tuition fees and course-related costs of up to MUR 100,000 ; Monthly living allowance to the value of MUR 12,500

Frequency: Annual

Country of Study: South Africa

Application Procedure: Apply online: ministry-education. govmu.org/English/scholarships/Documents/2018/Applica tion\%20Form\%20undergraduate\%20MASS\%2012Jan2018. pdf
Closing Date: 25 March

Funding: Foundation

For further information contact:

Email: internationalscholarships@dhet.gov.za

\section{New Zealand: Scholarships for International Tertiary Students and Commonwealth Scholarship}

Purpose: The New Zealand Aid Programme offers scholarships to potential applicants from eligible African countries (including South Africa) who are motivated to make a difference at home. Applications are now open for studies

Level of Study: Postgraduate

Type: Scholarship

Frequency: Annual

Country of Study: Any country

Application Procedure: All applications for the New Zealand Scholarship for International Tertiary Students must be submitted online. Please see the below links for more details on the process: All applications for the New Zealand Commonwealth Scholarship must be submitted on this application form. www.internationalscholarships.dhet.gov.za/Con tent/NEW ZEALAND/Tertiary Application Form 2019 Selection - Commonwealth.pdf

Closing Date: 28 March

Funding: Foundation

\section{For further information contact:}

Email: commonwealthscholarship@dhet.gov.za

\section{Romania: Romanian State Scholarships}

Purpose: The Romanian Ministry of Foreign Affairs (MFA) and the Romanian Department of Public, Cultural and Scientific Diplomacy are offering 85 scholarship opportunities to foreign citizens, to study in Romania. This opportunity is open to students who wish to pursue studies in Bachelor's, Master's and PhD. Courses will be taught in Romanian language

Eligibility: 1. Applicants must be in good health and have a strong academic record. 2. Must present study papers issued by accredited / recognized educational institutions. 3. Applicants must not be older than 35 years of age for Bachelor's and Master's studies and 45 years respectively for Doctoral studies, by 31 December of the year in which they are nominated. 4. Candidates must be prepared to fund any costs not covered by the scholarship 
Level of Study: Postgraduate

Type: Scholarship

Value: $€ 85$

Frequency: Annual

Country of Study: South Africa

Closing Date: 28 February

Funding: Foundation

\section{For further information contact:}

Email: internationalscholarships@dhet.gov.za

\section{Romanian State Scholarships}

Purpose: The Romanian Ministry of Foreign Affairs (MFA) and the Romanian Department of Public, Cultural and Scientific Diplomacy are offering 85 scholarship opportunities to foreign citizens, to study in Romania. This opportunity is open to students who wish to pursue studies in Bachelor's, Master's and $\mathrm{PhD}$

Eligibility: 1. Applicants must be in good health and have a strong academic record. 2. Must present study papers issued by accredited / recognized educational institutions. 3. Applicants must not be older than 35 years of age for Bachelor's and Master's studies and 45 years respectively for Doctoral studies, by 31 December of the year in which they are nominated. 4. Candidates must be prepared to fund any costs not covered by the scholarship

Level of Study: Postgraduate

Type: Scholarship

Value: $€ 85$

Length of Study: 1 year

Frequency: Annual

Country of Study: South Africa

Application Procedure: Apply online: www.mae.ro/en/ node/10251\#null

Closing Date: 28 February

Funding: Foundation

\section{For further information contact:}

Email: internationalscholarships@dhet.gov.za

\section{Russia: Scholarships for South Africans}

Purpose: The Russian Government offers annual scholarships for South Africans to study at Russian institutions. The scholarship is offered for Bachelor's, Masters and $\mathrm{PhD}$ degrees. Most programmes are taught in the Russian language. Scholarship recipients are required to undertake a preparatory course related to their field of study (including language training) for one year before pursuing their degree studies. Only after passing the examinations of the college preparatory course can they start their degree studies

Eligibility: 1. South African citizens in good health (medical test are required for successful applicants). 2. Have a strong academic record. 3. Demonstrated interest in Russia and commitment to the development of South Africa. 4. Applications in all fields of study except medicine will be considered. 5. Preference will be given to postgraduate applicants, previously disadvantaged applicants and applicants in the following fields

Level of Study: Postgraduate

Type: Scholarship

Frequency: Annual

Country of Study: South Africa

Application Procedure: Apply online: www.russia.study/en Closing Date: 27 February

Funding: Foundation

\section{For further information contact:}

Email: Internationalscholarships@dhet.gov.za

\section{Spain: Student and staff exchange between South Africa and Spain}

Purpose: Alianza 4 Universidades (A4U) is a consortium of four Spanish public universities. The consortium is funded by the Erasmus + Programme of the European Union to enable student and staff exchange between universities members of the A4U and six South African partner universities

Eligibility: 1. Applicants from South African partner universities and A4U universities. South African partner universities include: University of Pretoria, University of the Witwatersrand, Stellenbosch University, University of Cape Town, University of the Western Cape and University of the Free State. 2. A4U Universities participating universities are Universitat Autònoma de Barcelona, Universidad Autónoma de Madrid, Universidad Carlos III de Madrid and Universitat Pompeu Fabra in Barcelona

Level of Study: Postgraduate

Type: Grant

Frequency: Annual

Country of Study: South Africa

Application Procedure: Apply online: alliance4universities. eu/en/mobility-scholarships/

Closing Date: December

Funding: Foundation

\section{For further information contact:}

Tel: (34) 935422079

Email: coordinacion@a-4u.eu 


\section{Sweden: Swedish Institute Scholarships for South Africa (SISSA)}

Purpose: The Swedish Institute Scholarships for South Africa (SISSA) are being offered for South Africans to undertake Master's degrees at Swedish universities from September

Eligibility: 1. South African citizens in good health with a strong academic record. 2. Must have Bachelor's with Honours or equivalent, and should have performed well in his/her previous studies with minimum $65 \%$ average mark achieved. 3. Have applied for a Master's degree programme at a Swedish university on a full-time basis. 4. Intend to return to South Africa at the end of your studies. 5. Work and leadership experience is not a requirement but will be viewed favourably

Level of Study: Postgraduate

Type: Scholarship

Frequency: Annual

Country of Study: South Africa

Application Procedure: Apply online: si.se/en/apply/schol arships/swedish-institute-scholarships-for-south-africa/

Closing Date: 15 January

Funding: Foundation

\section{For further information contact:}

Email: Internationalscholarships@dhet.gov.za

\section{Switzerland: Swiss Government Excellence Scholarship for foreign students}

Purpose: Through the Swiss Federal Commission for Scholarships for Foreign Students, the Swiss Government Grants foreign researchers, postgraduate scholarships at Swiss higher education institutions. The Swiss Government Excellence Scholarship are intended for highly motivated, competitive young researchers who have graduated from university. These scholarships will enable applicants to undertake research work in the fields in which the Swiss universities are particularly active

Eligibility: 1. South African citizens. 2. Applicants with admission letter from academic host institution. 3. Support letter from supervisor or academic host professor. 4. Research proposal including timeframe

Level of Study: Postgraduate

Type: Scholarship

Value: 1,920 Swiss

Length of Study: 1 year

Frequency: Annual

Country of Study: South Africa
Application Procedure: Apply online: www. internationalscholarships.dhet.gov.za/Content/Switzerland/ 153_PhD_en_2019_20.pdf

Closing Date: 15 December

Funding: Foundation

For further information contact:

Tel: (27) 124520660

Email: pre.vertretung@eda.admin.ch

\section{Turkey: Türkiye Scholarships}

Purpose: Turkey is offering various scholarships to outstanding international students from across the world to study in the most prestigious universities in Turkey

Eligibility: 1. Applications for Türkiye Scholarships are open to citizens of all countries. 2. Applicants should not be older than 21 for Bachelor's, 30 for Master's and 35 for Doctoral studies. 3. For Undergraduate degree applications $70 \%$. 4. For Master's and Doctoral degree applications $75 \%$

Level of Study: Postgraduate

Type: Scholarship

Value: TRY 1,400

Frequency: Annual

Country of Study: South Africa

Application Procedure: Apply online: www.turkiyeburslari. gov.tr

Closing Date: 20 February

Funding: Foundation

For further information contact:

Email: info@turkiyeburslari.org

\section{United Arab Emirates: Khalifa University Postgraduate Scholarships}

Purpose: Khalifa University (KU) of Science and Technology is offering postgraduate scholarships to students who wish to pursue postgraduate studies in the field of Engineering Sciences in Abu Dhabi. Through these scholarships, the University aims to highlight the importance of investing in intellectual and human capital as well as its role in enhancing the performance of higher education system

Eligibility: Check website: www.ku.ac.ae/admissions/ graduate-admissions/

Level of Study: Postgraduate

Type: Scholarship

Frequency: Annual 
Country of Study: South Africa

Application Procedure: Apply online: admissions.kustar.ac. ae/pg/Account/Login

Closing Date: 30 April

Funding: Foundation

\section{For further information contact:}

Email: pgadmission@ku.ac.ae

\section{United States: Fulbright Foreign Student Program}

Purpose: The scholarship provides grants for South African university graduates to pursue a Master's or Doctoral degree at a United States university in any subject (excludes studies that require contact with patients). The grants are awarded for two years towards one degree - Master's or Doctorate (renewable each year)

Eligibility: 1. Be a South African citizen. 2. Usually between 30 and 45 years of age. 3. Have a 4-year B Tech or a 3-year Bachelor's degree plus Honours when applying for Master's.

4. Have a Master's degree when applying for a Doctoral degree. 5. Have proven academic excellence

Level of Study: Postgraduate

Type: Studentship

Value: Tuition fee and living stipend

Frequency: Annual

Country of Study: South Africa

Application Procedure: In order to apply for this scholarship, you could use the following link. apply.iie.org/ ffsp2020

Closing Date: 19 April

Funding: Private

Additional Information: For further, kindly contact the organisation using the below link. za.usembassy.gov/ education-culture/educational-exchanges/fulbright-flagshipprograms/foreign-student-program-frequently-asked-questions/

\section{United States: Harvard South Africa Fellowship Program}

Subjects: Harvard South Africa Fellowship Program (HSAFP) was established for mid-career professionals who were disadvantaged by past laws and resource allocations in South Africa

Purpose: The HSAFP was initiated to provide educational enrichment for mid-career individuals in various occupations who have shown considerable skills and leadership in their chosen fields. Applications are invited for the Harvard South Africa Fellowship Program
Eligibility: 1. Fellows must be South African citizens. 2. Usually between 30 and 45 years of age. 3. Must not have just completed or not completed a Bachelor's degree, unless this degree has been pursued concurrently with or subsequent to experience in the workplace. 4. Applicants should determine well in advance whether if awarded a fellowship, they can be granted leave by their employers for Harvard's academic year Level of Study: Postgraduate

Type: Fellowships, operating grants

Frequency: Annual

Country of Study: South Africa

Application Procedure: Apply onlline: africa.harvard.edu/ south-africa-fellowship-program

Closing Date: 4 April

Funding: Foundation

\section{For further information contact:}

Tel: $\quad$ (27) 877010715

Email: AfricaOffice@Harvard.edu

\section{Hilda Martindale Educational Trust}

Royal Holloway, University of London, Egham, TW20 0EX, Surrey, United Kingdom

Tel: (44) 1784276158

Fax: (44) 1784437520

Email: hildamartindaletrust@rhul.ac.uk

Contact: Miss Sarah Moffat, Administrator to the Trust

The Hilda Martindale Trust makes one-off awards to British women undertaking training or professional qualifications in areas in which women are underrepresented.

\section{Hilda Martindale Trust Awards}

Subjects: All subjects where women are under represented Purpose: To assist with the costs of training or professional qualifications in areas in which women are under represented Eligibility: Open to women of the British Isles only. Assistance is not given to short courses, courses abroad, elective studies or access courses. Trust can only offer funding to women pursuing training/qualifications in areas in which women are under represented

Level of Study: Doctorate, Graduate, Postdoctorate, Postgraduate, Predoctorate, Professional development, MBA, Undergraduate, Postgraduate (MSc)

Type: Grant 
Value: Up to $£ 3,000$

Length of Study: 1 year

Frequency: Annual

Study Establishment: Any establishment approved by the trustees

Country of Study: United Kingdom

No. of awards offered: 55

Application Procedure: The application form and guidance for applicants are available from the website address below. In addition, requests for an application form can be made by email to Hildamartindaletrust@rhul.ac.uk, or by letter via the address below. Late or retrospective applications will not be considered

Closing Date: Available from the secretary or on the Trust website: www.royalholloway.ac.uk/aboutus/governancematters/ thehildamartindaletrust.aspx

Funding: Private

Contributor: Private trust

No. of awards given last year: 16

No. of applicants last year: 55

Additional Information: Further information can be obtained via email at hildamartindaletrust@rhul.ac.uk.

\section{For further information contact:}

C/o College Secretary's Office, RHUL, Egham, TW20 0EX, Surrey, United Kingdom

Email: hildamartindaletrust@rhul.ac.uk

Contact: Secretary to the Hilda Martindale Trust

\section{Hong Kong Baptist University}

AAB703, Level 7, Academic and Administration Building, Baptist University Road Campus, Kowloon Tong, Hong Kong

Tel: (852) 34112188

Fax: (852) 34115568

Contact: Hong Kong Baptist University

Hong Kong Baptist University (HKBU) is a publicly funded tertiary institution with a Christian education heritage.

\section{Fully Funded Master Scholarship at Hong Kong Baptist University}

Subjects: The scholarship is awarded in International Journalism

Purpose: The aim of the scholarship is to encourage the study of International Journalism
Eligibility: Vietnam, Philippines, India and Indonesia. Applicants must have a valid minimum TOEFL iBT 79 or IELTS 6.5

Value: The scholarship is fully funded

Country of Study: Any country

Application Procedure: The mode of applying is online Closing Date: 28 February

Additional Information: For more details please see the website scholarship-positions.com/fully-funded-masterscholarship-hong-kong-baptist-university/2018/01/04/

For further information contact:

Email: busd-external@hkbu.edu.hk

\section{Horowitz Foundation for Social Policy}

PO Box 7, Rocky Hill, NJ 08553 0007, United States of America

Tel: $\quad$ (1) 7324452280

Fax: (1) 7326599198

Email: horowitz-foundation.org

Website: www.horowitz-foundation.org

Contact: Ms Mary E. Curtis, The Chairman

The Horowitz Foundation for Social Policy was established to support the advancement of research and understanding in the social sciences including: psychology, anthropology, sociology, economics, and political science. The Foundation assists individual scholars at the early stages of their career who require small grants to complete their dissertations.

\section{Irving Louis Horowitz Award}

Subjects: Social sciences, including anthropology, area studies, economics, political science, psychology, sociology, and urban studies, as well as newer areas such as evaluation research

Purpose: Awarded to the project that best represents the goals of the Horowitz Foundation in a specific award year

Eligibility: Open to nationals of any country. Candidates may solicit support for final work on a dissertation, including travel funds

Level of Study: Doctorate

Type: Award

Value: US $\$ 12,500$ (US\$10,000 initially and an additional US\$2,500 upon receipt of a final report on a copy of the research) 
Length of Study: 1 year

Frequency: Annual

Country of Study: Any country

No. of awards offered: 300

Application Procedure: Applicants are not required to be United States citizens or United States residents. Candidates may propose new projects, and they may also solicit support for research in progress, including final work on a dissertation, supplementing research in progress, or travel funds. Awards are only open to aspiring PhDs at the dissertation level whose project has received approval from their appropriate department head/university. Grants are normally made for 1 year on a non-renewable basis. Awards will be made to individuals, not institutions, and if processed through an institution, a waiver for overhead is requested. A copy of the product of the research is expected no later than 1 year after completion. Upon receipt an additional US\$2,500 will be paid. Recipients are expected to acknowledge assistance provided by the Foundation in any publication resulting from their research. Awards are publicized in appropriate professional media and on the Foundation website

Closing Date: 31 January

Funding: Private

No. of awards given last year: 15

No. of applicants last year: 300

Additional Information: The cover sheet in the application is most important, as it is the basis for the initial screening of prospects.

\section{For further information contact:}

Email: wagner.events@nyu.edu

\section{Refugee Study Awards}

Purpose: The Refugee Study Awards are for women who are studying for a New Zealand tertiary qualification, and who have not been through the New Zealand school system. The awards are a one off grant to help with study and/or living expenses

Eligibility: To apply for the Refugee Study Awards you must meet all the following eligibility criteria: The applicant is a woman, who: 1. Is enrolled in a NZ approved tertiary qualification. 2. Is studying at diploma or degree level (NZQA level 5 or above). 3. Is a New Zealand citizen or holds a resident class visa, and lives in New Zealand. 4. Provides evidence of having arrived in New Zealand as a refugee - ID card or NZ Immigration Service refugee travel document. Has not previously received a NHWT:HK Award

Level of Study: Graduate
Type: Award

Value: NZ \$3,000 -preference for an awardee from the Manawatu region, another is that $\$ 3,000$ - preference for an awardee from the Wellington region

Frequency: Annual

Country of Study: Any country

Application Procedure: Please check the following website link for further details. www.newhorizonsforwomen.org.nz/ awards/manawatu-charitable-trust-refugee/

Closing Date: 14 April

Funding: Private

Additional Information: One of these awards is sponsored by Graduate Women Manawatu Charitable Trust and preference will be given to applicants from Manawatu. The other award is sponsored by the Second Chance Group in Wellington and preference will be given to applicants from the greater Wellington region. Applications are welcome from women who are eligible from across the country.

\section{For further information contact:}

New Horizons for Women Trust, PO Box 12498, Wellington, NZL 6144, New Zealand

Email: enquiries@newhorizonsforwomen.org.nz

\section{The Horowitz Foundation for Social Policy}

Subjects: The Foundation makes targeted grants for work in all major areas of the social sciences, including anthropology, area studies, economics, political science, psychology, sociology, and urban studies, as well as newer areas such as evaluation research. Preference is given to projects that address contemporary issues in the social sciences and issues of policy relevance

Eligibility: Awards are open only to $\mathrm{PhD}$ candidates whose project has received approval from their appropriate department head/university. Preference is given to projects that address contemporary issues in the social sciences and issues of policy relevance. Applicants are not required to be citizens or residents of the United States. Awards are based solely on merit, not to ensure a representative base of recipients or disciplines

Level of Study: Doctorate

Type: Grants and fellowships

Value: $\$ 7,500-\$ 5,000$ initially and an additional $\$ 2,500$ upon completion of the project. Criteria for completion include approval of the dissertation, acceptance of an article based on the research by a peer-reviewed journal, or an invitation to write a book chapter based on the research. Additional awards are given in certain suspect areas. The best overall project (as determined by the trustees) receives an additional NZ $\$ 5,000$ 
Length of Study: NA

Frequency: Annual

Study Establishment: NA

Country of Study: Any country

No. of awards offered: 700

Application Procedure: Applications must be submitted through our online system which can be found on our website www.horowitz-foundation.org

Closing Date: 1 December

Funding: Private

Contributor: NA

No. of awards given last year: 20

No. of applicants last year: 700

Additional Information: All submitted applications, letters, and documents must be in English. Applications are open 1 July through 1 December. Applicants are encouraged to apply as early as possible. Submitted materials become the property of the Foundation and will not be returned. Applicants should not send originals or other materials that cannot be replaced

For further information contact:

Email: horowitz-foundation.org

\section{Hosei University}

17-1 Fujimi 2 chome, Chiyoda-ku, Tokyo JP 102, Japan

Tel: $\quad$ (81) 332649564

Fax: (81) 332389873

Email: ic@I.hosei.ac.jp

Website: www.hosei.ac.jp/ic

Contact: Ms Keiko Takahata, Executive Assistant

\section{Master of Business Administration Programme}

Application Procedure: Applicants must complete an application form supplying official transcripts, passport sized photograph, curriculum vitae and a statement of financial support

Closing Date: 30 November and 28 February

\section{For further information contact:}

Business Adminstration, 2-17-1 Fujimi, Tokyo 102, Japan

Tel: $\quad$ (81) 332649315

Fax: (81) 332389873

Email: ic@fujimi.hosei.ac.jp

Contact: MBA Admissions Officer

\section{Howard Hughes Medical Institute (HHMI)}

4000 Jones Bridge Road, Chevy Chase, MD 20815-6789, United States of America

Tel: $\quad$ (1) 3012158500

Website: www.hhmi.org

HHMI is a science philanthropy whose mission is to advance biomedical research and science education for the benefit of humanity. We empower exceptional scientists and students to pursue fundamental questions about living systems.

\section{Howard Hughes Medical Institute Gilliam Fellowships for Advanced Study}

Subjects: The Gilliam Fellowships for Advanced Study support exceptional graduate students who are committed to increasing diversity among scientific leaders, especially those students who will go on to become faculty members at colleges and universities

Purpose: The goal of the Gilliam Fellowships for Advanced Study program is to ensure the development of a diverse and highly trained workforce is available to assume leadership roles in science, including college and university faculty, who have the responsibility to teach the next generation of scientists

Eligibility: Open to alumni of HHMI's Exceptional Research Opportunities Program (EXROP), regardless of country of origin or nationally, or students nominated by T32 predoctoral training grant principal investigators (PIs) supported by the National Institute for General Medical Sciences (NIGMS); each nominated student must be training grant eligible but does not need to have been a T32 trainee

Type: Fellowship

Value: US $\$ 46,000$

Length of Study: Up to 3 years of their dissertation research, typically in years 3,4 , and 5 of their PhD studies

Frequency: Annual

Country of Study: United States of America

Closing Date: February

Additional Information: Please check details at www.hhmi. org/programs/gilliam-fellowships-for-advanced-study.

\section{For further information contact:}

Email: Gilliam@hhmi.org 


\section{Postdoctoral Research Fellowships for Physicians}

Subjects: Biological processes

Purpose: To help increase the supply of well-trained physician-scientists, through fellowships for three years of training in fundamental research (basic biological processes or disease mechanisms)

Eligibility: Applicants must have gained their first degree within the last ten years, and must have had two years of postgraduate clinical training, and no more than two years of postdoctoral training in fundamental research

Level of Study: Postdoctorate

Type: Fellowship

Value: US\$69,000-86,500 per year

Length of Study: 3 years

Frequency: Annual

Study Establishment: Academic or non-profit research institution

Country of Study: United States of America

No. of awards offered: 255

Application Procedure: Application forms and instructions should be obtained from the address shown. Panels of scientists review applications, and the Institute makes the final selection

Closing Date: Late December. Awards are announced in June No. of awards given last year: 30

No. of applicants last year: 255

Additional Information: Fellows must engage in full-time research. During the fellowship term, they may not be enrolled in a graduate degree program, nor hold a faculty appointment. The applicant is responsible for selecting a research mentor and making arrangements to work in that person's laboratory.

\section{For further information contact:}

4000 Jones Bridge Road, Chevy Chase, MD 20815, United States of America

Tel: $\quad$ (1) 3012158889

Fax: (1) 3012158888

Email: fellows@hq.hhmi.org

\section{Humane Research Trust}

The Humane Research Trust, Brook House, 29 Bramhall Lane South, Bramhall, Stockport, SK7 2DN, Cheshire, United Kingdom
Tel:

(44) 1614398041

Fax:

(44) 1614393713

Email: info@humaneresearch.org.uk

Website: www.humaneresearch.org.uk

Contact: Jane McAllister, Trust Administrator

The Humane Research Trust is a national charity, which funds a range of unique medical research programmes on human illness at hospitals and universities around the country. In keeping with the philosophy of the Trust, none of the research involves animals and much of it seeks to establish and develop pioneering techniques that will replace animal intensive experiments.

\section{The Humane Research Trust Grant}

Subjects: Humane Research

Purpose: To encourage scientific programmes where the use of animals is replaced by other methods

Eligibility: Open to established scientific workers engaged in productive research. Nationals of any country are considered but for the sake of overseeing, projects should be undertaken in a United Kingdom establishment

Level of Study: Unrestricted

Type: Grant

Value: Varies. Please note there is no set limit to either the duration of a project or funding amount. These points will be discussed if the application is successful, however you still need to include in your application the amount of funding you require and an estimate of the duration

Length of Study: Varies

Frequency: Dependent on funds available

Study Establishment: Various

Country of Study: United Kingdom

No. of awards offered: 15

Application Procedure: Applicants must complete an application form, available on the website www.humaneresearch. org.uk. Please ensure you email all of the required documents, i.e. one fully complete application to info@humaneresearch. org.uk and post 10 hard copies to The Humane Research Trust Closing Date: Varies

Funding: Private

Contributor: Supporters and legacies

No. of awards given last year: 4

No. of applicants last year: 15

Additional Information: The Humane Research Trust is a registered charity and donations are encouraged

\section{For further information contact:}

Contact: Mrs Katy Wright, Trust Administrator 


\section{Humboldt University of Berlin}

Office for Promotion of Young Researchers in the Excellence Initiative, DEU 10099 Berlin Germany

Tel: (49) 3020931795

Email: hgs-grants@ @u-berlin.de

Contact: Humboldt Graduate School

\section{Humboldt Postdoc Scholarships}

Purpose: To support young researchers in taking the next step in their academic career after acquiring their $\mathrm{PhD}$

Eligibility: Eligible to excellent researchers who either already hold a $\mathrm{PhD}$ from Humboldt-Universität or are about to complete their doctorate at Humboldt-Universität zu Berlin and who wish to conduct a postdoctoral research project. Half of the scholarships will be awarded to women
Type: Scholarship

Value: $€ 1,500$ per month is awarded for up to 6 months, additional family allowances are available, travel expenses may be covered. In exceptional cases, funding can be extended for up to an additional 6 months

Study Establishment: Humboldt-Universität

Country of Study: Germany

Application Procedure: Applications can be received only via an online application portal

Closing Date: 1 April to 15 May for funding starting 1 August, 1 June to 15 July for funding starting 1 October, 1 September to 15 October for funding starting 1 February, 1 December to 15 January for funding starting 1 April

\section{For further information contact:}

Email: hgs-grants@hu-berlin.de 